The Moderating Influence of Client Sophistication on Relationships within Business-to-Business Credence Service Markets

\author{
Tony Garry ${ }^{1 *}$ and Tracy Harwood ${ }^{2}$ \\ 'Department of Management \\ University of Canterbury \\ ${ }^{2}$ Institute of Creative Technologies \\ De Montfort University \\ *Contact Address \\ Department of Commerce \\ College of Business and Economics \\ University of Canterbury \\ Private Bag 4800 \\ Christchurch 8140 \\ New Zealand \\ Tel: +64 336429878160 \\ Email: tony.garry@canterbury.ac.nz
}

Submitted to the Journal of Business and Industrial Marketing 


\begin{abstract}
Purpose: This paper reports on a study which aims to identify the characteristics and determinants of client sophistication within the UK corporate legal services market and to investigate its affect in determining the nature and essence of client-solicitor relationships.
\end{abstract}

Methodology/Approach: Uses depth interviews of a range of individuals involved in the selection and evaluation of legal services used by their organisations and practice lawyers working for a variety of regional and national law firms involved in the delivery of legal advice related to corporate and commercial issues.

Findings: Findings suggest the level of client sophistication has a moderating influence in a number of key areas. These are identified as: service evaluation criteria; interdependency and power; the atmosphere in which solicitor-client interactions take place and relationships develop; the nature of joint personal relational goals and the role of trust and extent of commitment.

Originality/value: Enriches the limited literature on business-to-business credence services and develops a deeper understanding of the nature of relationships within such contexts.

Paper type: Research Paper

Key words: Business-to-Business, Professional Services, Credence Markets, Relationship Marketing, Consumer Expertise. 


\section{Introduction}

Much of the research conducted on the nature of relationships within professional services has assumed that they largely occur within a 'credence' market context (e.g. Morgan, 1991) and therefore " a consumer may not be able to evaluate the good, even after purchase and consumption due to the level of knowledge required to understand what the good does" (Alford and Sherrill, 1996: p. 72). However, the law literature suggests this may not always be the case. There is evidence to suggest that customers within certain credence contexts are heterogeneous. In such cases, customers may possess the ability to form expectation and performance assessments about the service they are receiving and they may have pertinent technical qualifications, skills, knowledge and experience that enable them to do so (e.g. Hanlon, 1997).

This has fundamental implications for the way service expectations are set, evaluations of service delivery are made and the nature and characteristics of the client-solicitor relationship. However, much of the marketing literature has largely ignored the concept of client sophistication and its implications on marketing efforts to foster relationships within credence markets. To this end, this paper reports on a study which seeks to: identify the characteristics and determinants of client sophistication within a business-tobusiness credence market (corporate legal services) and; to investigate its role in determining the nature and characteristics of client-solicitor relationships. By doing so, it attempts to enrich the limited literature on business-to-business credence services and develops a deeper understanding of the nature of relationships within such contexts. 
The paper is structured as follows. First, there is a brief synopsis of the relevant literature on the legal services market. Subsequently, the research methodology is described and key findings presented and discussed. Managerial implications are proposed and future research directions suggested before the paper ends with a conclusion.

\section{Literature Review}

The contextual focus of this paper is the study of interactions and relationships within the English corporate legal services market. To understand the wider influences and unique contextual characteristics that affect these relationships, it is necessary to explore the evolution and development of the legal profession within the UK and to identify and explain the key drivers of change within this context.

Until the 1970s, theories of the professions were generally functionalist in perspective (Parker, 1994). Within this theoretical framework, professionals were viewed as altruistic, working to serve society by using their specialised knowledge and skills to help people. However, subsequent research has reflected more controversial perspectives (e.g. Parker, 1997) which view the relationship between professionals, their clients and society as one which is based on monopolies of power; namely expert power (technical knowledge), social power (social status) and economic power (market control through regulation). This is largely attributable to the way the professions evolved within the UK. The development of professions and more specifically, that of the legal profession may be traced back to the Middle Ages (Hart and Hogg, 1998). During this period, the aristocracy largely led a 'leisured life' without active work. However, this lifestyle was 
only viable for the eldest son of the family. The professions of the Law, the Church and the Army provided the younger sons with a socially acceptable way of making a living. As a result, the professions became synonymous with the upper classes (Hart and Hogg, 1998). However, towards the end of the Middle Ages and beyond, a number of converging factors began to dissipate the market for professional expertise: the Reformation separated the Church and state in the $16^{\text {th }}$ Century; the Renaissance and the scientific advancement associated with it developed new boundaries of knowledge; the discovery of 'new worlds' and the expansion of commerce led to the growth of the merchant class in the $16^{\text {th }}$ Century and the subsequent industrial revolution. These factors led to the development of a newer set of 'occupational professions' including medicine, pharmacy and accountancy.

In response, the traditional professions attempted to differentiate their labour markets from others in society. This was achieved by engendering certain principles which became part of the defining characteristic of their professions (Hart and Hogg, 1998). From reviewing the literature a number of these defining characteristics may be identified. Firstly, there was an intrinsic assumption that the professions were essentially altruistic and that professionals were not motivated by commercial gain. The market operated upon what Snizek and Crocker (1985:p. 103) called the 'credot of caveatemptor-credat empter: let the buyer beware; let the consumer trust'. As a result, the professions were elevated to a special position in society because they embodied the values necessary "to prevent decay and anarchy" (Hart and Hogg, 1998: p. 56). Secondly, because of this privileged role in society and because of their specialised 
knowledge, the professions were able to develop exclusionary practices and barriers of entry. As a result, professions became specially regulated to ensure its practitioners “.... were all suitably trained and certified to interpret, develop, improve and supply this tradition for the benefit of others" (Parsons, 1954: p. 7). The professions evolved codes of ethics and standards that members were required to uphold. The results of these were to give the governing body of these professions power of control over the development of their profession thereby gaining economic prestige (Larsen , 1977) and to enhance the social prestige of its members ( Larsen , 1977).

However, complex and inter-related factors affecting the demand for legal services have resulted in the rapid transformation of the structure of the legal services market within the UK (Hanlon, 1997). These factors include 'individual and social decline' (e.g. criminal and divorce law etc); greater population diversity (e.g. anti-discriminate legislation); changes in wealth levels (e.g. wills and probate, capital gains, conveyancing etc) and the increasing complexities of business transactions (e.g. mergers and flotations). Changes in all these areas coupled with the deregulation of legal services markets has resulted in an unprecedented demand for legal services. The implications of this has been threefold: firstly, the growth of an 'advice culture' (Smith, 1996:p. 52) which is defined as "the increasing trend for people to seek advice in relation to both the material and psychological aspects of their problems". Secondly, the overall growth in the volume and complexity of legal procedures relating to both UK and European Union legislation. For example, Wall and Johnstone (1997) highlight the fact that although the number of Acts of Parliament and statutory instruments has remained fairly constant since 1951, the 
number of pages covered by such acts has tripled. Thirdly, there has been an overall permeation of the law at every level of society. Galanter (1992) goes as far as to describe this as a 'legal explosion' and as long ago as the 1970s Barton uses phrases such as 'excessive litigation and liability crisis' resulting from our "recondite anxieties about the bureaucratisation of the world" to describe the phenomenon.

Consensus within the law literature (e.g. Hanlon, 1997; Parker, 1997) suggests that, as a result of this increased demand, the legal profession is evolving into two generalised spheres of speciality; those firms primarily engaged in corporate and commercial work and those firms engaged in work for individual clients. Historically, this division was arbitrary because companies were effectively operated as private entities with the owners and a small number of managers running the firm. Thus, solicitors would largely have similar relational experiences when dealing with clients whether this related to private or commercial issues. Hanlon (1997) summarises the characteristics of such relationships as follows: solicitors were generally acting for clients who were 'articulate middle class landowners and business people' ( p. 801); solicitors would have been viewed as social equals (or even inferiors) by their clients and lastly; the relationship would have been on a long term, personal basis as traditionally clients rarely changed lawyers (Hanlon, 1997).

However, the changing nature of the commercial environment of the 1960 s meant the nature of the relationship between client and solicitor was transformed for a number of reasons. Firstly, there was a marked increase in the number of mergers and take-overs taking place in the financial 'City' of London. Between 1957 and 1967, 30\% of all 
publicly quoted firms in the UK were acquired by other publicly quoted firms (Hanlon, 1997). Secondly, as a result of this increased commercial activity, some law firms began to focus on expanding their services to corporate clients and downgrading or eliminating other areas of legal work perhaps involving private clients. Thirdly, the organisational structure of many client firms moved away from that of an owner-managed structure to one of a large multi-divisional management structure increasingly dominated by professional, non-owning personnel. Larger business organisations also began to establish or expand in-house legal departments. Consequently, the psychological mindset of these in-house lawyers was that of a 'career orientated corporate officer' rather than that of a legal professional (Spangler, 1986).

As a result, the corporate legal services market now comprises of a continuum of client sophistication. At one end of the continuum, are small owner-managed organisations that are largely unfamiliar with the law. At the other end are larger, more sophisticated clients with in-house legal expertise. Despite this, the marketing literature on credence services has tended to assume such clients are largely homogenous insofar as they are not qualified and/or do not possess experiential expertise to gauge the attributes of the service or product they are receiving (e.g. Alford and Sherrell, 1996). This research attempts to address this gap in the marketing literature by examining the implications of client sophistication on the way service expectations are set, evaluations of service delivery are made and relationships managed by the parties involved. To this end, the research had two primary objectives: firstly, to identify the characteristics and determinants of client 
sophistication and secondly; to investigate its role in determining the nature of clientsolicitor relationships within corporate law markets.

\section{Methodology}

Given the nature of the objectives, it was deemed imperative that a range of perspectives and interpretations of individuals from within the corporate legal services market should be gathered. This was particularly pertinent within this sectorial context because of the lack of information within the literature relating to consumer sophistication and professional services (Houghton and Winklhofer, 2004). Thus, a qualitative approach was judged to be appropriate as it accommodates 'deep' and 'rich' insights (Geertz, 1973), involves observation and recording of complex human behaviour and social systems (e.g. Feyerabend, 1981; Toulmin, 1972; Popper, 1965) and is useful for examining developing social processes (Hartley, 1994). In order to gain an in-depth understanding of the dynamics and characteristics of client-solicitor interactions, eighteen users and providers of corporate legal services were interviewed. A purposive sampling approach was used in order to recruit interviewees and ensure an appropriate spread of client sophistication. On the demand side, eight interviews were conducted with individuals involved in the selection and evaluation of legal services used by their organisations. These interviewees consisted of in-house lawyers working for large blue chip or public sector organisations and owner-managers of small or medium sized enterprises (SMEs) (see Appendix 1: Table I). On the supply side, interviewees consisted of ten practice lawyers working for a range of regional and national law firms involved in the delivery of legal advice related to corporate and commercial issues (see Appendix 1: Table II). A discussion guide was 
developed and used as a starting point from which respondents could elaborate on their responses through researcher probing. Subject issues raised in the course of the interviews included: environmental issues surrounding the corporate legal services market (e.g. the IMP Group, 1982); marketing orientation and marketing activities (e.g. Narver and Slater, 1990); relationship development, maintenance and termination (e.g. Dwyer et al., 1987); the role of the technical and functional elements of the service (e.g. Grönroos, 1984); the role of client sophistication; the role of trust and commitment (e.g. Morgan and Hunt, 1994) and the role of Affect (e.g. Alford and Sherrell, 1996). Each interview lasted around 30 minutes. The interviews were taped and subsequently transcribed onto hard copy to facilitate subsequent content analysis.

Data obtained from the interviews was transcribed and analyzed through content analysis following Goulding's (2001) framework of analysis. Firstly, interpretation of the data (clustering data into categories); secondly, identifying interrelationships between clusters and finally; re-evaluation. In the first level of analysis, data categories centred on the key research questions of identifying the characteristics and determinants of client sophistication within a business-to-business credence market and investigating its role in determining the nature and characteristics of client-solicitor relationships. At the second level of analysis, (identifying Interrelationships) contrasting, complementary or similar themes across the interview schedule were noted. For the third level of analysis (reevaluation), all coded data categories were checked and links with themes in previous literature noted; in particular, evidence of attitudes/practices found to support or contradict findings from previous studies. 


\section{Key Findings}

Findings are reported in seven key areas (see Figure I): firstly, the identification and nature of client sophistication and secondly; its role in determining service evaluation criteria and the processes of service evaluation. Thirdly, how client sophistication may impact on the nature of relationships in terms of interdependency and power. Fourthly, the atmosphere in which solicitor-client interactions take place and relationships develop. Fifthly, the nature of joint personal relational goals. Sixthly, the role of trust and lastly; the extent of commitment. Each of these is now examined in more depth.

Insert fig 1 about here

\section{The Characteristics of Client Sophistication and its Affect on Service Evaluation}

The research confirms that variations exist in the extent of sophistication among clients related to their knowledge of the law and legal services. Determinants of sophistication were primarily identified as being related to the possession of a legal qualification such as a law degree (LLB) or post-graduate legal qualification such as an LLM or LPC (Legal Practice Certificate) or its equivalent. As Hill and Motes (1995: p.7) state: "the expertise of the professional is often the outcome of extended academic preparation rather than the result of technical/on-the-job training". Whilst this perspective has traditionally been 
associated with the supplier of a professional service, these findings suggest this may also be appropriate for some purchasers of business-to-business professional services. A second determinant of client sophistication was identified as their experiential knowledge. Whilst some clients have relatively little experience of law and legal services, others had served as articled clerks, solicitors or even partners within private practice law firms prior to being selected and recruited 'in-house' with commercial or public sector organisations

These findings suggest corporate legal services may be chosen, consumed and evaluated by a qualified professional who possesses a high degree of legal and experiential knowledge. This in turn will affect the client's ability to issue instructions to solicitors acting on their behalf; understand the features and benefits of the service they are receiving and to gauge the components of the service delivery related to these. Where 'performance ambiguity' (Solomon et al., 1985) exists, as with less sophisticated clients, the quality of the technical or legal component of the service is determined by an evaluation of other aspects of the service interaction such as attributes of the functional component (Grönroos, 1984) . Thus, these 'demand peripherals' (e.g. Morgan and Hunt; 1994) may take on a higher degree of significance for clients with less expertise. As one solicitor states;

"I think they [less sophisticated clients] probably assume that [legal] knowledge is already assumed so they don't actually ask you questions about legal knowledge.....but the kind of thing that would make them go elsewhere is the fact that you only have two receptionists and they had to wait ten rings for the phone to be answered"

Solicitor A 
The analysis also identified the existence of an affective element evoked by the relationship and evidence suggesting the inability of some less sophisticated clients to distinguish between Affect evoked as a result of a satisfactory service delivery and Affect evoked as a result of interaction with the service provider (e.g. Alford and Sherrell, 1996). Solicitor D states "[the less sophisticated client] will go around the lawyers that are available until he finds a person he likes and feels comfortable with" and Solicitor I suggests "They [the client firm] then indicate that there's certain people they'll deal with, certain people they won't. So part of it must be simply the ability of the client...individuals to get on”. The mechanisms and processes for assessing the legal service appear to follow similar patterns. Whilst less sophisticated clients often used ad hoc assessment criteria based on perceptual judgments, more sophisticated clients used more complex mechanisms and processes:

"They [the client firm] will audit our files in terms of costs and results....they will consistently consider the advice that we're giving to see whether they agree with it....they will certainly look unfavourably on us if we don't return phone calls, emails, letters within a reasonable time"

Solicitor E

Hence, the level of client sophistication has fundamental implications for the way service expectations are set, evaluations of service delivery are made and the relationship is managed by either party. One solicitor very succinctly illustrates these implications:

"They [referring to more sophisticated clients] will have a pretty good idea as to what the cost of that service is in the market place. They will also have a pretty good idea of what the expertise is of the [private 
practice law] firms that they might want to use. That is a very different situation if, for example, you have a chap who's built up a business which is his sole asset and he's thinking of retiring and he wants to sell it.....It follows in terms of the corporate Plc client, the relationship element of the transaction between them and the professional advisor is less important by quite a long way than it would be with the man who's selling his life's work. He needs to have confidence in the relationship"

Solicitor B

These implications are now explored in more depth.

\section{The Power Dimension and its Affect on the Atmosphere of the Relationship}

The uniqueness of each individual client-solicitor relationship and the 'atmosphere' (IMP Group, 1982) in which it occurred was emphasised by respondents. There was clear evidence of the moderating role of a power dimension in dictating the nature of the relational atmosphere. Sources of power emanated primarily from the relevant legal expertise of the individuals involved at a dyadic level and the relevant size of the firms they represented and its corresponding buying power at an inter-organisational level. Very often these two factors were inextricable linked as it was the larger organisations that were likely to have in-house legal departments. The extent and nature of exertion of power by one party or another would dictate whether the atmosphere was characterised by an ethos of co-operation, friendship and mutual assistance or a more calculative approach in terms of a focus on resource maximisation. Competing economic and sociological perspectives combined with the concept of client sophistication provided interesting insights into extreme and distinct types of relational behaviour that were identified. Montgomery (1998) distinguishes between two archetypal relational orientations. Firstly, a heuristic perspective revolving around socialised 'friends' who will 'co-operate as a matter of principal' (p. 92). This reflects the perceived atmosphere 
surrounding some less sophisticated client-solicitor relationships. For example, Solicitor $\mathrm{C}$ states that with the less sophisticated client there is "...a much more informal and friendly approach" and solicitor D states “....with the owner managed clients, it is in terms of relationships...you know, personal relationships". In contrast, the second archetype relational orientation is characterised by decisions guided by utility utilisation sometimes to the point of 'self-interest seeking with guile' (Williamson, 1985:p. 47). Interviewees tended to associate this type of approach with larger and more sophisticated clients. For example, Solicitor F illustrates how this may effect the relational atmosphere of client-solicitor interaction:

"Buying power with very sophisticated clients is a concern because if a firm [corporate client] becomes large enough to dictate terms, it's possible and it is happening, that they are insisting upon better terms from the [law] firms. What they're doing is they're threatening to reduce panels [preferred suppliers] further, which is in turn encouraging the solicitors who provide their service to be more flexible ......and once they've encouraged that debate .....they're almost competitive tendering. The [law] firms that are left are in a much weaker position than they were because they're reliant upon an awful lot of work from a major buyer"

Solicitor F

Where there had been a perceived misuse of power, a termination in the relationship may result:

"If a client were to be so powerful as to strike deals that were not economic with a firm of solicitors of our size, I think that would result in termination of the relationship. ... and certainly some firms in my market.... we heard decided recently to terminate the relationship with large clients on the basis that the client had gone too far in dictating not only the fees but also the extra services which must be provided for nothing."

Solicitor I 
In reality, the differing archetypes illustrated above are likely to be more complex and subtle in nature in terms of, for example, relationships exhibiting characteristics of both (Heide and Wathne, 2006).

\section{Joint Personal Relational Goals and Shared Values}

The importance of joint personal relational goals and shared values (Morgan and Hunt, 1994) at an organisational and individual level were emphasised by respondents. With some client-solicitor relationships, these expectations and goals were inextricable linked to those of the client organisation and were perceived as being explicit. If the individual client was dissatisfied then the relationship with the client organisation was effectively terminated. This was particularly the case with less sophisticated clients such as ownermanagers. With some, more sophisticated clients, tacit and implicit personal interaction goals existed. Frequently, there was an understanding between individuals that these were of a long term strategic nature and were anticipated to be mutually beneficial. As one solicitor highlighted, these often revolved around enhancing each other's career progression: "[it involves finding out] how are they being judged by their boss...working with them to facilitate their role and make them look good". It was anticipated that such relationships would continue even when individuals changed organisations to progress their career. It is implicit practice within the corporate legal services market that when a solicitor is 'headhunted' from one law firm to another, they will attempt to take key client accounts with them to their new firm on the basis of the strength of their relationships. This may culminate in clients 'following' their solicitor to another law. Indeed, one respondent had switched law firms as a result of their partner solicitor being successfully 
headhunted. Solicitor D alludes to how, in extreme cases, such personal relationships may be potent barriers to competitive entry:

"We hear all of these horror stories from the Plc clients about their relationship with the City [law] firms. It annoys the hell out of us because we get the pilchards..... and they [the City law firms] are basically treating them [their clients] like dirt .... the Plc's chairman probably went to Eton with the senior partner of the City firm!"

Solicitor D

From a managerial perspective, there was an awareness of the risks of over reliance on a dyadic relationship revolving around two individuals between two organisations and that such individual involvement in relationships may have to be managed in some circumstances to avoid solicitors defecting and taking key clients with them. Solicitor G illustrates this point and how it might be managed;

"....So in terms of managing your stars [the key solicitor in a relationship] , you need to try to have people that clients like and think they're terrific and so on...but you have to have them [the clients] comfortable with dealing with a broader group of people so that when there's some huge new or different transaction, then they can have their star ...you know that's fine ...but what is better for us as a firm .....for them as well .....is that it's really a number of three or four people who they feel comfortable dealing with"

Solicitor G

The Role of Trust

Trust is primarily related to a cognitive and rational appraisal (Lewis and Weigert, 1985) of the technical and functional components of the service. Interestingly, for all respondents, the professional quality of the technical component (i.e. the legal advice) is 
largely perceived as a hygiene factor and is implicit within the service offering. From a client perspective, this trust in the technical component emanates from three sources: confidence in the extended academic preparation of the professional; secondly, the existence of a formal professional body which set levels of competence and standards (i.e. The Law Society) and thirdly; the intuitive logic of the respondent and the experiential consistency with which the service process is performed. For less sophisticated clients this implicit trust also extends to fees charged because of difficulties they have in making direct performance assessments and comparisons with competitors. However, for those clients with the necessary level of expertise, fees charged and its negotiation is a critical contributor towards trust for both sides in the relationships. Client A illustrates the implications of a breach of trust related to fee negotiation;

\begin{abstract}
"We had a deal with them [supplying firm of solicitors] and they [a competitor that the client had recently acquired] have a deal with them and we would have thought, as we spend a lot more with them and are a much more important client [than the recently acquired rival], we would have achieved a better deal and we found out we didn't....it's a real negative point in terms of the relationship. We went through hours of negotiations with their people [the firm of solicitors].....they told us we were doing very well....did they tell us the truth?"
\end{abstract}

\title{
Client A
}

At a different level, another form of less calculative trust was also identified. This revolved around trusting people because 'of who they are' (Barney and Hansen, 1994) and resulted from 'evaluations of goodwill and good character' ( Ayios and Harris, 2005: p. 456). This type of trust was more prevalent in less sophisticated client-solicitor relationships. So, for example, Solicitor G states: 
"I think having people who like and trust you and think that you care about them..... and actually it does help if you genuinely do care about the relationship ... you need someone to feel this thing is theirs"

Solicitor G

\section{The Extent of Commitment}

These findings suggests that more sophisticated clients tended to be less committed to any single relationship. There was an increasing recognition that "there is a wide array of high quality partners to choose from" and "we consider it commercially advantageous [to use a number of firms of solicitors] to ensure checks and balances are maintained between them' (Client A). Many of the interviewees cited the practice of 'panelling' by more sophisticated clients. Clients will reduce, through a tendering process, the number of law firms they use. The remaining law firms receive larger amounts of business but with expectations that costs will be reduced and/ or productivity increased. Panels are reviewed periodically and law firms that are perceived as providing poor quality of service or poor value for money are replaced. Another reason cited for changing law firms by larger clients were take-overs and mergers. This may occur because the dominant partner in the take-over or merger uses different law firms on their panel and a rationalisation process occurs where law firms are 'dropped'. Less sophisticated clients were more likely to be committed to a relationship with a single law firm. Palmatier et al's (2006) research within consumer markets suggest consumers are more likely to be committed where they have a higher degree of control over the selection criteria. Similarly, the respondents from SMEs are likely to have a higher degree of control over their organisational actions in terms of their choice of law firms and thus are possible more committed. If one extends 
the marriage metaphor (e.g. Tynan, 1997) then the relationship between firms and clients traditionally characterised as monogamous still, to a large extent, appears to exist with less sophisticated clients. However, with more sophisticated clients, polygamy has become the norm with concurrent relationships existing with a number of law firms.

\section{Discussion}

Complex and inter-related factors continue to bring about a rapid transformation of the structure of the legal services market within the UK. Whilst the legal sector has 'traditionally eschewed marketing activities' (Harris et al, 2003: p. 15), evidence suggests (Hanlon, 1997) that larger law firms operating in the business-to-business sector are now endorsing the commercialisation of legal services. This is culminating in such firms reorganising their structures and redefining their perception of professionalism to incorporate and engender a stronger commercial/entrepreneurial element. On one hand, this involves a downgrading of values such as public service and citizenship and on the other, an increasing priority being attached to market values such as the ability to generate profits and establishing and maintaining mutually beneficial and on going relationships with clients. However, when considering the relational literature, it is important to consider the unique nature and characteristics of client-law firm interactions within business-to-business legal services.

Studies that have focused on relationship length alone as a measure of loyalty are increasingly being questioned for a variety of reasons for which there is evidence within these findings. Both short-term and longer term customers may be profitable (Reinartz 
and Kumar, 2002). Long-term customers may not always be cheaper to serve and may be as price sensitive (Dowling and Uncles, 1997). Also, the value of long-term customers may vary 'substantially with the category' (East et al., 2006: p. 12). Instead, other measures of loyalty that recognise customer polygamy and serial monogamy (Rust et al., 2004) such as 'share of wallet' are being proposed (Cooil et al., 2007). These measures would certainly appear to be more appropriate within this research context. Associated with this is the extent of client 'Relationship Orientation' (RO). Whilst at one level, RO encompasses individuals at a dyadic level and manifests itself in terms of the strength of a relationship (e.g. trust), at another level, more recent research refers to 'the firm's aptitude towards institutionalising an effective relationship building culture' (Winklhofer et al., 2006:p. 170). From a demand perspective, these results suggest that the sophistication of the client institution may contribute towards its relational orientation and ultimately, the nature and characteristics of dyadic client-solicitor relationships. This in turn, has implications from a supply perspective.

\section{Managerial Implications}

Previous research on marketing relationships has highlighted the importance of distinguishing between individual-level and firm-level variables (e.g. Macintosh, 2005; Sirdeshmukh et al., 2002; Iacobucci and Ostrom, 1996). Whilst most law firms recognise the importance of developing strong relationships with clients, they also need to consider that a potentially stronger relationship may be established at the interpersonal level between their employees and clients. Such relationships are recognised by many as being mutually beneficial and powerful enablers within the legal profession at both a 
professional and personal level. Employees within law firms should, where appropriate, be assessed on their ability to develop ongoing and stable relationships with clients rather than purely on specified fee earning and financial targets. Related to this, organisational reward systems should reflect an employees ability to determine "what kind of relationship is sought and in what circumstances" (Blois, 1996) by clients and which clients are likely to reciprocate attempts at relational enhancement by investing 'resources, efforts and attention' (Camarero, 2007:409) in relationships with their law firms.

\section{Future Research}

Related to the above, a potential future research area is the construct of 'attraction' between relational partners. Whilst much of the research focus surrounding attractiveness has been centred on economic benefits, there is an increasing appreciation of the role of social compatibility, particularly within a professional services context (e.g. Harris et al., 2003). These findings suggest there is scope for further research into the relationship between interaction, Affect evoked as a result of interaction and attraction judgments. It would also be interesting to identify if, and to what extent, client sophistication may moderate perceived economic and social attractiveness within such relational contexts. In particular, attractiveness and its relationship to the strategic component of the dimension of 'joint personal interaction expectations and goals' identified may provide stimulating insights into the characteristics of dyadic relationships within a professional services business-to-business context. 
Another potential research area relates to the investigation of the relational orientations of organisations. Whilst there was evidence to support differing relational orientations, these appear to be associated with individuals at a dyadic level rather than the relationship orientation of an organisation as a whole. An interesting avenue of research would be to investigate the organisational perspective of relationship orientation to ascertain the extent that relationship orientation is 'culturally embedded' (Winklhofer et al., $2006 \mathrm{p}$. 171) at an institutional level.

\section{Conclusion}

These findings contribute towards our contextual understanding of what has traditionally been classified as a 'credence' service context. Current literature generally suggests credence attributes are not assessable even after purchase and consumers must rely 'essentially on trust and faith' ( Mittal ,2004: p. 450). However, these results suggest that there may be consumers with appropriate levels of sophistication who are in a position to make assessments on service delivery within credence contexts. Thus, a determinant factor as to how service expectations are set and evaluations of service delivery are made is the level of consumer sophistication rather than the attributes of the service being delivered. This in turn appears to have a moderating influence in determining the nature and characteristics of client-solicitor relationships. 


\section{Acknowledgement}

The authors wish to thank Christine Ennew and Sally McKechnie of the University of Nottingham for their advice, guidance, encouragement and support during the course of this research 


\section{References}

Alford, B. \& Sherrell, D. (1996), The Role of Affect in Consumer Satisfaction of Credence- Based Services, Journal of Business Research, 37: 71-84.

Ayios, A. and Harris, L., (2005), "Customer Relationships in the e-economy: Mutual Friends or Just Veneering", Qualitative Market Research: An International Journal, 8 (4), 454-469

Bagozzi, R. P. (1992), The Self Regulation of Attitudes, Intentions and Behaviour, Social Psychology Quarterly, 55: 178-204.

Barney, J. and Hansen, M., (1994), "Trustworthiness as a Source of Competitive Advantage”, Strategic Management Journal, 15, 175-90

Barton, K. (1975), Beyond the Legal Explosion, Standford Law Review, 47.

Cooil, B., Keiningham, T., Aksoy, L. and Hsu, M., (2007), A Longitudinal Analysis of Customer Satisfaction and Share of Wallet: Investigating the Moderating Effect of Customer Characteristics, Journal of Marketing, 71 (January): 67-83.

Dowling, G. and Uncles, M., (1997), Do Customer Loyalty Programs Really Work, Sloan Management Review, 38 (Summer) 71-82

Dwyer, F. Schurr, P. \& Oh, S. (1987), Developing Buyer - Seller Relationships, Journal of Marketing Management, 51(2): 11 - 27.

East, R., Hammond, K. and Gendall, P., (2006) Fact and Fallacy in Retention Marketing, Journal of Marketing Management, 22: 5-23

Elkman, P. (1992), An Argument for Basic Emotions, Cognition and Emotion, In: O. R.L. (Ed.), Satisfaction: A Behavioural Perspective on the Consumer: 169-200: McGrawHill International.

Feyerabend, P. (1981), Philosophical Papers:Vol. 1, Realism, rationalisation and scientific method,. Cambridge.

Galanter, M. (1992), Law abounding: Legislation around the North Atlantic. Modern Law Review, 5(1): 1-24.

Goulding, C. (2001) Grounded Theory: A Magical Formula or a Potential Nightmare, The Marketing Review, Vol 2, pp. 21-34

Grönroos, C. (1984), A Service Quality Model and its Marketing Implications. 
Hanlon, G. (1997), A Profession in Transition? - Lawyers, The Market and Significant Others. The Modern Law Review, 60(6): 798-822.

Harris, L. O'Malley, L. \& Patterson, M. (2003), Professional Interaction: Exploring the Concept of Attraction. Marketing Theory, 3(1): 9-36.

Hart, S. \& Hogg, (1998), Relationship Marketing in Corporate Legal Services. The Service Industries Journal, 18(3): 55-69.

Heide, J. and Wathne, H., (2006),'Friends, Businesspeople, and Relationship Roles: A Conceptual Framework and a Research Agenda", Journal of Marketing, 70 (July), 90-103

Hill, C. J. \& Motes, W. H. (1995), Professional Versus Generic Retail Services: New Insights. Journal of Services Marketing, 9(2),

Houghton, K. and Winklhofer, H., (2004), The Effect of Website and E-Commerce Adoption on the Relationship between SMEs and their Export Intermediaries, International Small Business Journal, 22(4): 369-388

Iacobucci, D. and Ostrom, A., (1996), "Commercial and Interpersonal Relationships: Using the Structure of Interpersonal Relationships to Understand Individual Individualto-individual, Individual-to-firm and Firm-to-firm Relationships in Commerce", International Journal of Research in Marketing, Vol. 13, pp53-72

IMP, Group. (1982), "International Marketing and Purchasing of Industrial Good". In D. Ford (Ed.), Understanding Business Markets: Interactions, Relationships and Networks: 10-27. London: Academic Press.

Izard, C. E. (1972), Patterns of Emotion. New York: Academic Press.

Larson, M. (1977), The Rise of Professionalism. Berkeley: University of California Press.

Lewis, D. and Weigert, A., (1985), “Trust as a Social Reality”, Social Forces, 63 (4), 967-85

Macintosh, G., (2005), "Customer Orientation, Relationship Quality, and Relational Benefits to the Firm", Journal of Services Marketing, Vol. 21, No. 3: pp. 150-159

Morgan, R. M. \& Hunt, S. D. (1994), The Commitment - Trust Theory of Relationship Marketing. Journal of Marketing Management, 58(July): 20 - 38.

Montgomery, J., (1998), "Towards a Role-Theoretic Conception of Embeddedness". American Journal of Sociology 104 (1), 92-125

Narver, J. C. \& Slater, S. F. (1990), The Effect of a Market Orientation on Business Profitability. Journal of Marketing(October): 20-35. 
Palmatier, R. Dant, R. Grewal, D. and Evans, K. (2006), "Factors Influencing the Effectiveness of Relationship Marketing: A Meta Analysis". Journal of Marketing, 70(October): 136-153

Parker, C. (1997), Competing Images of the Legal Profession: Competing Regulatory Strategies. Industrial Journal of Sociology of Law, 25: 385-409.

Parsons, T. (1954), A Sociologist looks at the legal profession, Essays in Sociological Theory: 370-385. Illinois: Free Press.

Popper, K. (1965), Conjectures and Refutations: The growth of scientific knowledge. New York: Harper and Row.

Reinartz, W. and Kumar, V. (2002), The Mismanagement of Customer Loyalty, Harvard Business Review, July, 86-94

Roseman, I. J. (1991), Appraisal Determinants of Discrete Emotions. Cognition and Emotion, 5: 161-200.

Rust, R.T., Lemon, K. and Zeithaml, V., (2004), Return on Marketing: Using Customer Equity to Focus Marketing Strategy, Journal of Marketing 68 (January) 109-127

Sirdeshmukh, D., Singh, J. and Sabol, B., (2002), "Consumer Trust, Value and Loyalty in Relational Exchanges”, Journal of Marketing, Vol. 66 (January), pp. 15-37.

Smith, R. (1996), Legal Aid and Justice. In D. Bean (Ed.), Law Reform for All. London: Blackstone Press.

Snizek \& Crocker. (1985), From a Gentleman's to a Public Profession Status: Politics in the History of English Solicitors. Industrial Journal of the Legal Professions, 3(45-80),

Solomon, M. Suprenant, C. Czepiel, J. \& Gutman, E. (1985), A Role Theoretical Perspective on Dyadic Interactions: The Service Encounters. Journal of Marketing, 49(Winter): 99-111

Spangler, E. (1986), Lawyers for Hire-Salaried Professional at Work. New Haven: Yale University Press.

Toumlins, S., (1972), Human Understanding: The Collective use and Evolution of Concepts, Princeton, NJ., Princeton University Press

Tynan, C. (1997), A Review of the Marriage Analogy in Relationship Marketing. Journal of Marketing Management, 13: 695-703.

Williamson, O., (1985), Markets and Hierarchies: Analysis and Antitrust Implications, New York: The Free Press 
Wall, D. \& Johnstone, J. (1997), The Industrialisation of Legal Practice and the Rise of the New Electric Lawyer: The Impact of Information Technology upon Legal Practice in the UK [1]. International Journal of the Sociology of Law, 25: 95-116.

Winklhofer, H, Pressey, A. and Tzokas, N. (2006), A Cultural Perspective of

Relationship Orientation: Using Organisational Culture to Support a Supply Relationship Orientation, Journal of Marketing Management, 22: 169-194 
Appendix 1: Details of Interviewees

\begin{tabular}{|c|c|c|c|}
\hline$\frac{\text { Respondent }}{\underline{\text { Code }}}$ & $\frac{\text { Respondent }}{\underline{\text { Profile }}}$ & $\frac{\begin{array}{c}\text { Size of } \\
\text { Organisation }\end{array}}{\underline{\text { Employees) }}}$ & $\frac{\text { Brief Description of }}{\underline{\text { Organisation }}}$ \\
\hline Client A: & In-house Lawyer (Male) & 3,181 & Global Merchant Bank \\
\hline Client B & In-house Lawyer (Female) & 2,475 & International Cosmetics Company \\
\hline Client C & In-house Lawyer (Male) & 15,174 & Regional County Council \\
\hline Client D & Company Secretary(Female) & 4 & Construction \\
\hline Client E & Director (Female) & 2 & Management Consultant \\
\hline Client F & Senior Chemist (Male) & $\begin{array}{c}95,000 \\
\text { (worldwide) }\end{array}$ & Pharmaceutical Company \\
\hline Client $\mathrm{G}$ & Financial Advisor (Male) & 72 & Investment Brokers \\
\hline Client $\mathrm{H}$ & Director of Estates (Female) & 3000 & University \\
\hline
\end{tabular}

Table I: Details of Interviewees on the Demand Side of the Corporate Legal Services Market

\begin{tabular}{|c|c|c|}
\hline Respondent Code & Respondent Profile & Size of Law Firm \\
\hline & & $\frac{1}{\text { (No. of Partners) }}$ \\
\hline Solicitor A & & 27 \\
\hline Solicitor B & Partner (Male) & 41 \\
\hline Solicitor C & Partner (Male) & 14 \\
\hline Solicitor D & Solicitor (Male) & 65 \\
\hline Solicitor E & Partner (Male) & 104 \\
\hline Solicitor F & Partner (Female) & 194 \\
\hline Solicitor G & Partner (Male) & 8 \\
\hline Solicitor H & Partner (Female) & 11 \\
\hline Solicitor I & Partner (Male) & 289 \\
\hline Solicitor J & Associate Partner (Male) & \\
\hline
\end{tabular}

Table II: Details of Interviewees on the Supply Side of the Corporate Legal Services Market 
Fig.1

Low level

High level

of Client Sophistication

of Client Sophistication

\begin{tabular}{|c|c|c|}
\hline & $\underline{\text { Comparison Criteria }}$ & \\
\hline $\begin{array}{l}\text { Focus on functional and affective } \\
\text { elements }\end{array}$ & Evaluation Criteria and Processes & $\begin{array}{l}\text { Focus primarily on technical elements } \\
\text { with functional element and subordinate } \\
\text { affective element }\end{array}$ \\
\hline $\begin{array}{c}\text { Process of evaluation is generally } \\
\text { informal }\end{array}$ & & $\begin{array}{c}\text { Process of evaluation is often formalised } \\
\text { assessment of technical and functional } \\
\text { product }\end{array}$ \\
\hline $\begin{array}{c}\text { Usually balance with law firm and based } \\
\text { on knowledge power }\end{array}$ & Power Dimension & $\begin{array}{c}\text { Often balance with client and based on } \\
\text { buying power }\end{array}$ \\
\hline $\begin{array}{l}\text { Often informal and friendly } \\
\text { (co-operative) }\end{array}$ & Atmosphere of Relationship & $\begin{array}{c}\text { Formal } \\
\text { (often confrontational) }\end{array}$ \\
\hline $\begin{array}{c}\text { Usually intertwined with fortunes of } \\
\text { organisation }\end{array}$ & Joint Personal Relational Goals & Long term and mutually career orientated \\
\hline $\begin{array}{c}\text { Based on professional position but also on } \\
\text { personal characteristics }\end{array}$ & The Role of Trust & Based on professional position \\
\hline $\begin{array}{l}\text { Usually one and sometimes two legal } \\
\text { suppliers with longer term commitment }\end{array}$ & The Extent of Commitment & $\begin{array}{l}\text { 'Panels' of law firms used who are } \\
\text { continually assessed and compared with } \\
\text { each other to ensure resource utilisation. } \\
\text { Limited commitment and possible short } \\
\text { term }\end{array}$ \\
\hline
\end{tabular}

Figure I: The Affect of Client Sophistication on Client-Solicitor Relationships 